\title{
OPTIMIZATION OF FACTORS AFFECTING THE Agrobacterium tumefaciens- MEDIATED TRANSFORMATION OF Eucalyptus saligna ${ }^{1}$
}

Yohana de Oliveira-Cauduro ${ }^{2 *}$, Lais Gomes Adamuchio ${ }^{3}$, João Carlos Bespalhok Filho ${ }^{4}$, Isabel Rodrigues Gerhardt $^{5}$, Juliana Degenhardt-Goldbach ${ }^{6}$, Marianne Bernardes ${ }^{7}$ and Marguerite Quoirin ${ }^{8}$

\footnotetext{
${ }^{1}$ Received on 03.04.2014 accepted for publication on 27.04.2017.

${ }^{2}$ Universidade Federal do Paraná, Doutorado em Produção Vegetal, Pitanga, Paraná, Brasil. E-mail: <yohanacauduro@gmail.com>.

${ }^{3}$ Universidade Federal do Paraná, Mestrado em Produção Vegetal, Curitiba, Paraná, Brasil. E-mail: <laisgadamuchio@hotmail.com>.

${ }^{4}$ Nagoya University,Doutorado em Agricultura, Japão. E-mail: <bespa@ufpr.br>.

${ }^{5}$ Universidade de Brasília, Doutorado em Ciência Biológica, Distrito Federal-Brasilia, Brasil. E-mail: <isabel.gerhardt@embrapa.br>.

${ }^{6}$ Leibniz Universitat Hannover, Doutorado em Ciências da Horticultura, Alemanha. E-mail: <juliana.degenhardt@embrapa.br>.

${ }^{7}$ Universidade Federal do Paraná, Graduada em Biologia, Colombo, Paraná, Brasil. E-mail: <mariannebernardes@gmail.com>.

${ }^{8}$ Universidade Federal do Paraná, Doutorado em Produção Agronomia, Curitiba, Paraná, Brasil. E-mail: <mquoirin@ufpr.br>.

*Corresponding author.
}

\begin{abstract}
This study aimed to evaluate the effect of factors that may affect the genetic transformation of cotiledonary explants of Eucalyptus saligna mediated by EHA105 strain of Agrobacterium tumefaciens. The vector pBI121 carrying gus gene under control of 35S CaMV promoter was used. The effect of the following factors was evaluated: explant pre-culture, use of different antibiotics and presence of acetosyringone (AS) in co-culture media. An antioxidant solution was also used during excision, containing ascorbic acid (250 $\left.\mathrm{mg}^{-\mathrm{L}^{-1}}\right)$, citric acid $\left(25 \mathrm{mg} . \mathrm{L}^{-1}\right)$ and PVP-40 $\left(1 \mathrm{~g} . \mathrm{L}^{-1}\right)$. Pre-culture of the explants before the co-culture with bacteria was done over a 4-day period in MS culture medium supplemented with 4.4 $\mu \mathrm{M}$ BAP and 2.7iM NAA. After the co-culture period, three concentrations of kanamycin $\left(12.5 ; 25\right.$ and 50mg.L $\left.\mathrm{L}^{-1}\right)$ combined with $300 \mathrm{mg} . \mathrm{L}^{-1}$ Augmentin $^{\circledR}$ in the culture medium were tested The influence of the antibiotic was also evaluated by keeping the explants in a medium containing 50mg. $\mathrm{L}^{-1} \mathrm{Km}$ and $300 \mathrm{mg} . \mathrm{L}^{-1}$ Augmentin ${ }^{\circledR}$ or 500mg. $\mathrm{L}^{-1}$ cefotaxime. It was concluded that Augmentin ${ }^{\circledR}$ stimulates organogenesis, that a Km concentration of $12.5 \mathrm{mg} . \mathrm{L}^{-1}$ allows selection of explants transformed with gus gene and, finally, the addition of AS (50iM) to the liquid and solid co-culture media has a positive effect on gus gene expression. Moreover, the use of an antioxidant solution during cotyledon excision is dispensable and the pre-culture of the explants has no effect on bud regeneration or gus gene expression. A transformation efficiency of $1.5 \%$ was reached.
\end{abstract}

Keywords: Acetosyringone; Antibiotic; Kanamycin

\section{OTIMIZAÇÃO DE FATORES QUE AFETAM A TRANSFORMAÇÃO GENÉTICA DE Eucalyptus saligna MEDIADA POR Agrobacterium tumefaciens}

\begin{abstract}
RESUMO - Esse trabalho teve como objetivo avaliar o efeito de vários fatores que podem afetar a transformação genética de explantes cotiledonares de Eucalyptus saligna mediante co-cultura com a cepa EHA105 de Agrobacterium tumefaciens. Foi utilizado o vector pBI121 carregando o gene repórter gus sob controle do promotor $35 S C a M V$. Foi estudado o efeito dos fatores a seguir: pré-cultura dos explantes, uso de diferentes antibióticos e presença de acetosiringona (AS) nos meios de co-cultura. Uma solução contendo ácido ascórbico (250mg. $\left.L^{-1}\right)$, ácido cítrico (25mg. $\left.L^{-1}\right)$ e PVP-40 (1g.L $\left.L^{-1}\right)$ foi utilizada no momento da excisão dos explantes. A pré-cultura dos explantes antes da co-cultura com a bactéria foi de 4 dias, em meio de cultura MS suplementado de 4,4 $\mu M$ BAP e 2,7ì ANA. Após a co-cultura três concentrações de canamicina (12,5; 25 e 50mg. $\left.L^{-1}\right)$ combinadas com $300 \mathrm{mg} . L^{-1}$ de Augmentin ${ }^{\circledR}$ no meio de cultura foram testadas. O efeito do Augmentin ${ }^{\circledR}\left(300 \mathrm{mg} . L^{-1}\right)$ nos explantes foi comparado ao da cefotaxima (500mg. $\mathrm{L}^{-1}$ ), em meio contendo $50 \mathrm{mg} . \mathrm{L}^{-1} \mathrm{de} \mathrm{Km}$. Foi concluído que Augmentin ${ }^{\circledR}$ estimula a organogênese, em comparação com a cefotaxima, que a concentração de $12,5 \mathrm{mg} . L^{-1}$
\end{abstract}


de Km permite a seleção de explantes transformados com o gene gus e, finalmente, a adição de AS (50iM) aos meios de co-cultura líquido e sólido tem efeito positivo sobre a expressão do gene gus. $O$ uso de antioxidante não é necessário e a pré-cultura dos explantes antes da inoculação com A. tumefaciens não tem efeito na regeneração de gemas nem na expressão do gene gus. A eficiência de transformação foi de 1,5\%.

Palavras-Chave: Acetosiringona; Antibiótico; Canamicina.

\section{INTRODUCTION}

Eucalyptus genus is economically important worldwide and represents one of the main sources of biomass (Girijashankar, 2011). In 2014, the total area planted with Eucalyptus in Brazil was approximately 5.6 million ha (SNIF, 2015) of which the main part was intended for paper and pulp production. In southern Brazil this industry relies primarily on plantations of E. saligna Smith and E.dunnii Maiden for cellulose supply (Fett-Neto et al., 2001). E. saligna is also one of the species with great potential for production of veneers and plywood panels for outdoor use (Iwakiri et al., 2013).

By conventional breeding methods, genetic improvement of forest trees is limited, due to their long breeding cycles, high level of heterozygosity and large segregated populations (McRae and Van Staden, 1999). Biotechnological methods are important as they reduce the long time needed for breeding. Several techniques of genetic transformation have already been applied to Eucalyptus species and A. tumefaciens-mediated protocols have been the most followed (Girijashankar, 2011). The biolistic method was used less frequently, but some reports indicate that it can be successfully applied, for example recently in the case of $E$. camaldulensis plants (Mendonça et al., 2013).

Dibax et al. (2010) established an A. tumefaciensmediated protocol for genetic transformation of $E$. saligna leaf explants, with an efficiency of transformation of $0.5 \%$ (1:200), indicating the need for an optimized protocol. Various factors may affect the success of plant transformation by indirect methods, some of them acting on bacteria virulence, others on the bud regeneration process. In the first case, the use of phenolic compounds that improve Agrobacterium virulence and then gene transfer into plant cells is important for transformation of some plant species. The co-culture period is also a crucial factor (Seong and Song, 2008). In the second case, a pre-culture period and treatment of explants with antioxidant compounds may improve the regeneration process (Seong and Song, 2008; Li et al., 2011). Kanamycin is an aminoglycoside antibiotic used to select the tissues transformed with $n p t$ II (kanamycin resistance) gene. Its concentration is speciesdependent and must be tested in each case. On the other hand, the antibiotics used to eliminate the agrobacteria after the co-culture can inhibit (Ogawa and Mii, 2005) or promote organogenesis (Danilova and Dolgikh, 2004).

This study aimed to evaluate the effect of some of these factors that may affect bud regeneration or transformation efficiency of E. saligna cotyledonary explants, such as explant treatment with an antioxidant solution, explant pre-culture, type of antibiotic used to eliminate the Agrobacterium after the co-culture and addition of acetosyringone into the co-culture media.

\section{MATERIALAND METHODS}

Plant material and in vitro culture. Cotyledons of E. saligna plantlets cultured in vitro were used as an explant source twelve days after sowing. The explants were cultured in Petri dishes $(2 \times 10 \mathrm{~cm})$, containing $25 \mathrm{ml}$ of culture media, sealed with PVC film and kept at $25 \pm 2^{\circ} \mathrm{C}$ under fluorescent tubes providing a cold white light with an irradiance of $47 \mu \mathrm{mol} \mathrm{m}^{-2} \mathrm{~s}^{-1}$ and a $16 \mathrm{~h}$ photoperiod. All culture media had their $\mathrm{pH}$ adjusted to 5.8 prior to autoclaving at $120^{\circ} \mathrm{C}$ for $20 \mathrm{~min}$.

Genetic transformation of $\boldsymbol{E}$. saligna. The protocol followed in this study was the one published by Dibax et al. (2010). The Agrobacterium tumefaciens strain used for the genetic transformation of E. saligna was EHA105 (Hood et al., 1993) containing the binary vector $\mathrm{pBI} 121$. This vector carried the â-glucuronidase reporter gene (gus), under control of the CaMV35S constitutive promoter, and the neomycin phosphotransferase selection marker gene (nptII) under control of nos promoter. Entire cotyledonary explants were immersed in a bacterial solution of $\mathrm{A}_{600}=0.6$ for $30 \mathrm{~min}$ in an orbital shaker (120 rpm). They were then cultured for five days on MS (Murashige and Skoog, 1962) medium with half concentrations of potassium

Revista Árvore. 2017;41(3):e410315 
and ammonium nitrates, 2.7 iM NAA, 4.4 iM BAP and $30 \mathrm{gL}^{-1}$ sucrose (Dibax et al., 2005). After this period, explants were transferred onto the selective medium (the same medium, supplemented with $\mathrm{Km}$ and cefotaxime (Cx) or Augmentin, according to the experiment). The histochemical assay for â-glucuronidase activity (Jefferson, 1987) was performed on 15 explants of each treatment five and twelve days after the bacterial inoculation. Explants with one or more blue region were considered gus positive.

Use of an antioxidant solution during explant excision. The treatments were: (a) explants in a solution containing ascorbic acid $\left(250 \mathrm{mg} . \mathrm{L}^{-1}\right)$, citric acid (25 mg. $\left.\mathrm{L}^{-1}\right)$ and polyvinylpyrrolidone (PVP40) (1 g.L.-1) at pH 5 (Tournier et al., 2003); (b) explants in autoclaved water. The explants were then co-cultured with the bacteria as described above. After co-culture on solid medium, the explants were transferred onto the same medium, supplemented with $250 \mathrm{mg} . \mathrm{L}^{-1} \mathrm{Cx}$ and $50 \mathrm{mg} \cdot \mathrm{L}^{-1} \mathrm{Km}$ and subcultured every $15 \mathrm{~d}$ in the dark. Each treatment consisted of four replicates of 50 cotyledons. The experiment was repeated once. The percentages of oxidized explants, explants forming calluses and forming buds were evaluated after 60 days.

Pre-culture of cotyledonary explants. The pre-culture consisted of four days on MS culture medium supplemented with 4.4 $\mu \mathrm{M}$ BAP and 2.7 iM NAA before co-culture with the bacterial suspension. The control was not pre-cultured. The cultures were kept in the dark. Each treatment consisted of four replicates of 50 explants, except in some cases indicated below. The experiment was repeated once. Gus gene expression was observed after $5 \mathrm{~d}$ and oxidized explants, callus formation, bud regeneration after $60 \mathrm{~d}$.

Kanamycin concentration. After the coculture period, the explants were cultured for $60 \mathrm{~d}$ on the same medium, supplemented with $300 \mathrm{mg} . \mathrm{L}^{-1}$ Augmentin $^{\circledR}$ - Sandoz (amoxicilin/clavulanic acid - 1g/ $125 \mathrm{mg})$ and $\mathrm{Km}\left(12.5,25\right.$ and $\left.50 \mathrm{mg} . \mathrm{L}^{-1}\right)$ in the dark and for another $60 \mathrm{~d}$ period under light. Subcultures on fresh medium were carried out every $15 \mathrm{~d}$. Each treatment consisted of five replicates of 20 explants.

Histochemical â-glucuronidase assay and PCR analysis were performed five and 180 days after explant infection. The experiment was repeated twice.
Bud regeneration in the presence of Augmentin or cefotaxime. At the end of the 5d-co-culture, the explants were transferred to the same medium supplemented with $50 \mathrm{mg} . \mathrm{L}^{-1} \mathrm{Km}$ and Augmentin ${ }^{\circledR}$ (300 mg.L. $\mathrm{L}^{-1}$ ) or Cx (500 mg.L $\left.\mathrm{L}^{-1}\right)$. Petri dishes were kept in the dark for $60 \mathrm{~d}$, being subcultured on fresh medium every $15 \mathrm{~d}$. After this period, the same evaluations were carried out as indicated above. Contamination of the explants with $A$. tumefaciens was also recorded. The treatments were composed of six replicates, with 20 explants each. The experiment was repeated once.

Acetosyringone and transformation efficiency. During the co-culture of the explants with the bacteria, $50 \mathrm{iM}$ of acetosyringone (AS) was added to the culture media, according to the following treatments: 1- addition to the liquid co-culture medium; 2- to the solid co-culture medium; 3 - to both co-culture media; 4- without addition and 5- control not inoculated with the bacteria. After the co-culture period the explants were transferred to the same culture medium supplemented with $\mathrm{Km}$ (50 mg.L $\left.\mathrm{L}^{-1}\right)$ and Augmentin ${ }^{\circledR}\left(300 \mathrm{mg} . \mathrm{L}^{-1}\right)$. The culture conditions and evaluation factors were those described above. Each treatment consisted of five replicates of 20 explants. Histochemical â-glucuronidase assay was carried out after 5 and $12 \mathrm{~d}$. The experiment was repeated once.

DNA extraction and PCR. DNA was extracted from three leaves of putatively transformed shoots $180 \mathrm{~d}$ after transformation and from control material not inoculated, and processed according to the protocol of Doyle and Doyle (1987). Putative transformed shoots were PCR-screened to detect the presence of gus reporter gene. Each reaction $(25 \mu \mathrm{l})$ contained $20 \mathrm{mM}$ Tris- $\mathrm{HCl}$ (pH 8.4), $50 \mathrm{mM} \mathrm{KCl}, 1.5$ $\mathrm{mM} \mathrm{MgCl}_{2}, 2 \mathrm{mM}$ of each dNTP, $1.0 \mathrm{U}$ of Taq polymerase, 50 ng DNA and $10 \mathrm{iM}$ of each oligonucleotide specific to the gus gene. Invitrogen's Taq DNA polymerase recombinant kit was used for DNA amplification. The following primer pair was used in the PCR assay: 5'CAGCGCGAAGTCTTTATATACCG-3' and 5' ATGCGTCACCACGGTGATATCG-3'. The samples were submitted to the following amplification programme in a thermocycler (Applied Biosystems, Veriti, 96 Well Thermal Cycler): $94^{\circ} \mathrm{C}$ for $3 \mathrm{~min}$, followed by 30 cycles of $94{ }^{\circ} \mathrm{C}$ for $1 \mathrm{~min}, 52{ }^{\circ} \mathrm{C}$ for $1 \mathrm{~min}, 72{ }^{\circ} \mathrm{C}$ for $1 \mathrm{~min}$, $72{ }^{\circ} \mathrm{C}$ for $7 \mathrm{~min}$ and $4{ }^{\circ} \mathrm{C}$ until application in the gel. After electrophoresis on $1.5 \%$ agarose (p/v) gel containing ethidium bromide $(0.5 \mu \mathrm{g})$, the PCR products were visualized under UV radiation.

Revista Árvore. 2017;41(3):e410315 
Experimental design and statistical analysis. In all experiments statistical design was totally randomized. Bartlett's test for homogeneity of variance was applied and means compared by Tukey's multiple range test using ASSISTAT software (Silva and Azevedo, 2009).

\section{RESULTS}

Effect of the use of an antioxidant solution during explant excision. There was no difference between treatments (Table 1). Oxidation rate was high (83.2 and $87.2 \%$ for antioxidant and water treatment, respectively) after $60 \mathrm{~d}$, indicating that the treatment was not efficient in controlling tissue oxidation. Callogenesis was observed in 62.8 and $63.6 \%$ of surviving explants and bud regeneration was low (Table 1).

Effect of explant pre-culture on transformation efficiency. The $4 \mathrm{~d}$ pre-culture did not affect the regeneration process and the results of oxidation and callogenesis were similar to those obtained in the previous experiment (results not shown). However, some bud regeneration was observed in both treatments (1.6 and $1.2 \%$ respectively for treated and untreated explants). Expression of the gus gene reached $20 \%$ of the explants in both cases (data not shown).

In the present study, pre-culture was not used in the following experiments.

Table 1 - Effect of treatment of cotiledonary explants of Eucalyptus saligna with an antioxidant solution* during excision and before inoculation with Agrobacterium tumefaciens. Mean of two experiments, evaluated after $60 \mathrm{~d}$ of culture.

Tabela 1 - Efeito do tratamento dos explantes cotiledonares de Eucalyptus saligna com uma solução antioxidante $*$ durante a excisão e antes da inoculação com Agrobacterium tumefaciens. Média de dois experimentos, avaliados após $60 \mathrm{~d}$ de cultura.

\begin{tabular}{lccc}
\hline Treatment & $\begin{array}{c}\text { Oxidiz } \\
\text { edexplants } \\
(\%) *\end{array}$ & $\begin{array}{c}\text { Explantswith } \\
\text { callus } \\
(\%)^{*}\end{array}$ & $\begin{array}{c}\text { Explants } \\
\text { with buds } \\
(\%)^{*}\end{array}$ \\
\hline Antioxidant & $83.2 \mathrm{a}$ & $62.8 \mathrm{a}$ & $2.4 \mathrm{a}$ \\
Water & $87.2 \mathrm{a}$ & $63.6 \mathrm{a}$ & $2.0 \mathrm{a}$ \\
\hline CV (\%) & 3.75 & 3.88 & 7.04 \\
\hline
\end{tabular}

Means followed by the same letter within a column do not differ significantly by Tukey's test at the 0.05 level. Culture medium: MS N/2 supplemented with $2.7 \mu \mathrm{M}$ NAA and $4.4 \mu \mathrm{M}$ BAP, 250 mg. $\mathrm{L}^{-1} \mathrm{Cx}$ and $50 \mathrm{mg} . \mathrm{L}^{-1}$ kanamycin. $*$ Ascorbic acid $\left(250 \mathrm{mg} . \mathrm{L}^{-1}\right)$, citric acid $\left(25 \mathrm{mg} . \mathrm{L}^{-1}\right)$ and PVP-40 $\left(1 \mathrm{~g} . \mathrm{L}^{-1}\right)$ at $\mathrm{pH}$ 5. $\mathrm{CV}=$ coefficient of variation.

Revista Árvore. 2017;41(3):e410315
Effect of kanamycin concentration in the selection of transformed tissues. Oxidation rate and callus formation were similar in the three treatments $\left(12.5,25\right.$ and $\left.50 \mathrm{mg} . \mathrm{L}^{-1} \mathrm{Km}\right) 60$ days after inoculation (Table 2). However, on a medium containing $12.5 \mathrm{mg} . \mathrm{L}^{-1} \mathrm{Km}$, a higher number of explants formed buds with a higher number of buds per explant than in the other treatments and, after $180 \mathrm{~d}$ in the same medium, more than 15 buds were counted in $12 \%$ of explants.

Every shoot that developed from an explant on selection medium was considered as an event and molecular analysis was carried out in order to detect the presence of escapes. PCR of 13 events, $180 \mathrm{~d}$ after inoculation, revealed the presence of the gus reporter gene in three of them (Figure 1). In this experiment, the efficiency of transformation was $1.5 \%(3 / 200)$, three times superior to that obtained by Dibax et al. (2010).

Effect of two antibiotics on bud regeneration in cotyledonary explants. In the presence of Augmentin, the oxidation rate of the explants was lower, while callus and bud formation were higher than in the presence of Cefotaxime (Cx) (Table 3). Some contamination with A. tumefaciens was still observed, mainly when Cx was used (Table 3 ).

Effect of acetosiringone (AS) on transformation efficiency. The analysis of transient expression of the gus gene, performed $5 \mathrm{~d}$ after the initiation of the co-culture, showed the effect of AS (Figure2). It was noted that AS positively affected this expression when added to liquid and solid media and $80 \%$ of the explants expressed the gus gene (T3). Twelve days after initiation of the co-culture, surprisingly the highest number of explants expressing the gus gene was observed in explants treated with liquid co-culture medium containing AS (50\%) (Figure 2). At this time, expression is already stable.

\section{DISCUSSION}

In Eucalyptus species, tissue browning frequently induces a reduction of growth and may lead to explant death. Several antioxidants may be used to avoid this phenomenon. PVP is a polyamide that impedes the oxidation and polymerization of phenolic compounds (Zhou et al., 2010). Ascorbic acid does not act directly on polyphenoloxidases but avoids the browning of 
Table 2 - Gus gene expression and organogenesis in Eucalyptus saligna cotyledonary explants in selective medium containing different concentrations of kanamycin. Mean of two experiments.

Tabela 2 - Expressão do gene gus e organogênese em explantes cotiledonares de Eucalyptus saligna em meio de seleção contendo diferentes concentrações de canamicina. Média de dois experimentos.

\begin{tabular}{|c|c|c|c|c|c|c|c|}
\hline \multirow[b]{2}{*}{$\begin{array}{c}\mathrm{KmGus} \text { gene } \\
\left(\mathrm{mg} \cdot \mathrm{L}^{-1}\right)\end{array}$} & \multirow[b]{2}{*}{$\begin{array}{c}\text { Oxidized } \\
\text { Expression }\end{array}$} & \multicolumn{4}{|c|}{$\begin{array}{l}60 \text { days } \\
\text { afterinoculation }\end{array}$} & \multicolumn{2}{|c|}{$\begin{array}{l}180 \text { days after } \\
\text { inoculation }\end{array}$} \\
\hline & & $\begin{array}{l}\text { Explants } \\
\text { explants }\end{array}$ & $\begin{array}{c}\text { Explants } \\
\text { with callus }\end{array}$ & $\begin{array}{l}\text { Mean number of } \\
\text { with buds }\end{array}$ & $\begin{array}{c}\text { Explants } \\
\text { buds/ }\end{array}$ & $\begin{array}{l}\text { Necrose } \\
\text { with buds }\end{array}$ & \\
\hline & $(\%)^{*}$ & $(\%)$ & $(\%)$ & $(\%)$ & explant $* *$ & $(\%)$ & $(\%)$ \\
\hline 12.5 & 40 & $31.99 \mathrm{a}$ & $67.7 \mathrm{a}$ & $24.0 \mathrm{a}$ & $3.90 \mathrm{a}$ & 12 & 88 \\
\hline 25 & 47 & $37.29 \mathrm{a}$ & $59.9 \mathrm{a}$ & $16.0 \mathrm{~b}$ & $2.53 \mathrm{~b}$ & 1 & 99 \\
\hline 50 & 33 & $37.96 \mathrm{a}$ & $63.9 \mathrm{a}$ & $14.6 \mathrm{~b}$ & $1.62 \mathrm{c}$ & 0 & 100 \\
\hline CV (\%) & & 26.3 & 20.1 & 8.2 & 17.06 & & \\
\hline
\end{tabular}

Means followed by the same letter in the column do not differ statistically by Tukey's test at the 0,05 level.

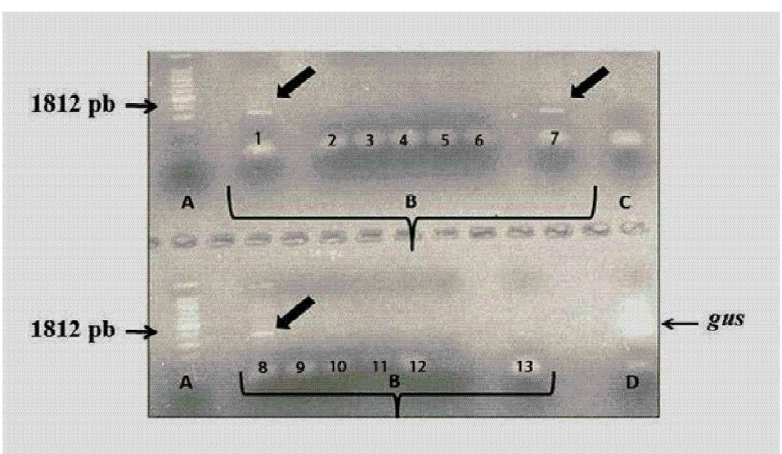

Figure 1 - Polymerase chain reaction amplification $(\mid \mathrm{PCR})$ of gus gene from a sample of putatively transformed shoots of Eucalyptus saligna. A. Molecular weight marker(Ladder $100 \mathrm{pb}$ ). B. Events 1 to 13: transformed with the gus gene and regenerated in the presence of kanamycin (arrows: gus gene). Events 1 to 7 with $12.5 \mathrm{mg} . \mathrm{L}^{-1} \mathrm{Km}$ and event 8 to 13 with $25 \mathrm{mg}$.. ${ }^{-1}$. C. Negative control. D. Positive control:pBI121 plasmid.

Figura 1 - Eletroforese dos produtos do PCR de DNA de Eucalyptus saligna. A. Marcador de peso molecular (100 pb). B. Eventos 1 a 13: transformados com o gene gus e regenerados na presença de canamicina (setas: gene gus). Eventos 1 a 7 com 12.5 mg. $L^{-1}$ $K m$ e eventos 8 a 13 with $25 \mathrm{mg} . \mathrm{L}^{-1}$. C. Controle negativo. D. Controle positivo: plasmideo pBI121.

the cultures by reducing oxidized substrates (Ahmad et al., 2013). It is a high spectrum antioxidant (Ali and Alqurainy, 2006; George and Davies, 2006; Suaréz et al., 2010). On the other hand, the antioxidant effect of citric acid is due to its ability to act as a chelating agent which traps ions that increase oxidation, especially copper. Copper is a component of polyphenoloxidases, but it also catalyses the reaction of inactivation of ascorbic acid by molecular oxygen (Nawar, 1996; Raju and Bawa, 2006). AC may therefore optimize the antioxidant effect of other compounds.
The antioxidant solution applied in this work was successfully used by Tournier et al. (2003) during the explant excision from E. grandis $\mathrm{x}$ E. urophylla leaves. For E. tereticornis, PVP (500 mg.L $\left.\mathrm{L}^{-1}\right)$ was efficient in controlling tissue oxidation (Subbaiah and Minocha, 1990). However, E. saligna material did not respond to this treatment and other concentrations of the antioxidants or their addition to the culture medium should be tested. Soaking of explants of Musa laterita in an antioxidant mixture of citric and ascorbic acids ( 50 or $100 \mathrm{mg} . \mathrm{L}^{-1}$ ) prior to their culture was effective in limiting phenolic exudation (Dayarani and Dhanarajan, 2013). The addition of reduced glutathione ( $25 \mathrm{mg} . \mathrm{L})$ and ascorbic acid (10 mg.L) to culture medium was also beneficial for the growth of Jatropha curcas shoots (Misra et al., 2010).

In the present study, a $4 \mathrm{~d}$ pre-culture of explants before the inoculation of the bacteria had no effect on gus gene expression or bud regeneration. However, in explants of $E$. grandis $\times E$. urophylla, a 2 d preculture affected positively the expression level of the gus gene (Alcantara et al., 2011). In the case of hypocotyl segments of E. camaldulensis, a 3 d pre-culture of the explants on B5C medium is followed by a $2 \mathrm{~d}$ coculture with the bacterium (Ho et al., 1998). Moralejo et al. (1998) also recommend a pre-culture of 4 to 6 $\mathrm{d}$ in order to increase the expression level of gus gene in cotyledons and hypocotyls of E. globulus. For $E$. tereticornis, a pre-culture of cotyledons and hypocotyls is also beneficial (Prakash and Gurumurthi, 2009). The difference between these and our results may be due to the type of explant (leaf/cotyledon/hypocotyl) or to the eucalyptus species or even to the composition of culture medium used during pre-culture, which was different in every case.

Revista Árvore. 2017;41(3):e410315 
Table 3 - Effect of Augmentin ${ }^{\circledR}$ and cefotaxime on indirect organogenesis in cotyledonary explants of Eucalyptus saligna inoculated with Agrobacterium tumefaciens, after 60 days of culture. Mean of two experiments.

Tabela 3 - Efeito de Augmentin e cefotaxima na organogênese indireta de explantes cotiledonares de Eucalyptus saligna inoculados com Agrobacterium tumefaciens aos 60 dias de cultura. Média de dois experimentos.

\begin{tabular}{|c|c|c|c|c|}
\hline Treatment & $\begin{array}{l}\text { Oxidiz } \\
\text { explants } \\
(\%)^{*}\end{array}$ & $\begin{array}{l}\text { Explants with } \\
\text { callus }(\%)^{*}\end{array}$ & $\begin{array}{l}\text { Explants } \\
\text { with buds } \\
(\%)^{*}\end{array}$ & $\begin{array}{c}\text { Contamination } \\
\text { by } A . \text { tumefaciens } \\
(\%)^{*}\end{array}$ \\
\hline Augmentin ${ }^{\mathbb{}}\left(300 \mathrm{mg} . \mathrm{L}^{-1}\right)$ & $56.3 \mathrm{~b}$ & $80.8 \mathrm{a}$ & $46.6 \mathrm{a}$ & $18.3 \mathrm{~b}$ \\
\hline Cefotaxime $\left(500 \mathrm{mg} \cdot \mathrm{L}^{-1}\right)$ & $79.1 \mathrm{a}$ & $64.1 \mathrm{~b}$ & $10.0 \mathrm{~b}$ & $40.0 \mathrm{a}$ \\
\hline CV (\%) & 10.4 & 4.1 & 25.7 & 19.7 \\
\hline
\end{tabular}

Means followed by the same letter in the column do not differ by Tukey's test at the 0.05 level. Culture medium: MS N/2 supplemented with $2.7 \mu \mathrm{M}$ NAA, $4.4 \mu \mathrm{M}$ BA and $50 \mathrm{mg} . \mathrm{L}^{-1} \mathrm{Km}$.

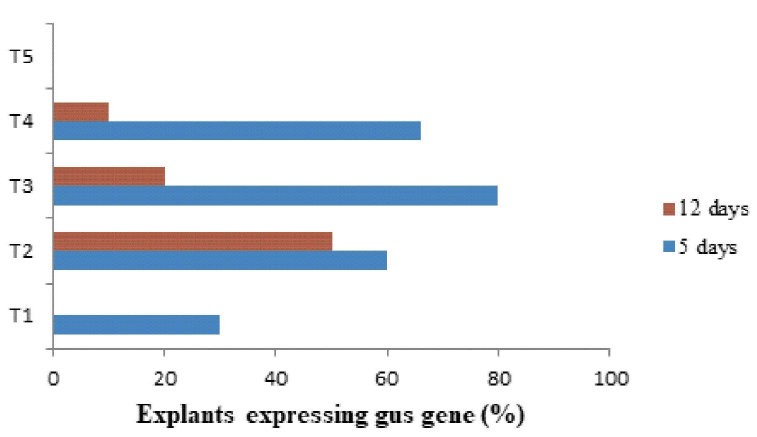

Figure 2 - Percentages of Eucalyptus saligna cotyledonary explants expressing the gus gene after 5 and 12 days of co-culture with Agrobacterium tumefaciens in the presence or absence of acetosyringone (AS). T1: AS $(50 \mu \mathrm{M})$ in solid co-culture medium. T2: AS in liquid co-culture medium. T3: AS in solid and liquid co-culture media. T4: control without AS. T5: non-inoculated control.

Figura 2-Percentagens de explantes cotiledonares de Eucalyptus saligna expressando o gene gus após 5 e 12 dias de co-cultura com Agrobacterium tumefaciens. T1: AS $(50 \mu M)$ no meio de co-cultura sólido. T2: AS no meio de co-cultura líquido. T3: AS nos meios de co-cultura sólido e líquido. T4: Controle sem AS. T5: Controle não inoculado.

Kanamycin is added to media after the co-culture period in order to select tissues transformed with a construction containing nptII gene. The concentration of $12.5 \mathrm{mg} . \mathrm{L}^{-1}$ was considered appropriate for cotyledonary tissues of E. saligna, as it allowed the selection of some events. The response of Eucalyptus to this kind of antibiotic varies with the species (Gonzales et al., 2000). For E. camaldulensis, $9 \mathrm{mg} . \mathrm{L}^{-1} \mathrm{Km}$ was sufficient to select transgenic shoots (Mullins et al., 1997; Quisen et al., 2009) while, for E. tereticornis, Prakash and Gurumurthi (2009) established an efficient protocol using $40 \mathrm{mg} . \mathrm{L}^{-1}$, and reaching 14.4 to $21.2 \%$ of transformation efficiency.
Augmentin added to the co-culture media was more efficient for bud regeneration than Cefotaxime. The same effect of Augmentin on bud regeneration was described for cotiledonary explants of $E$. camaldulensis (Quisen et al., 2009) co-cultured with the strain C58C1 of $A$. tumefaciens, where the antibiotic concentration was reduced from $300 \mathrm{mg} . \mathrm{L}^{-1}$ to $150 \mathrm{mg} . \mathrm{L}^{-1}$ after $15 \mathrm{~d}$ and then to $100 \mathrm{mg} . \mathrm{L}^{-1}$ after another $15 \mathrm{~d}$. The number of buds per explant (5.4) was similar to the number obtained in the present study. In peanut (Arachis hypogea), a combination of $200 \mathrm{mg} . \mathrm{L}^{-1} \mathrm{Cx}$ and the same concentration of Augmentin ${ }^{\circledR}$ was recommended to counteract the bacteria growth and to enhance the bud formation (Tiwari and Tuli, 2012). Augmentin is a mixture of amoxicillin and clavulanic acid. The former is an inhibitor of bacterial cell wall synthesis and the latter is an inhibitor of â-lactamase which protects amoxicillin from inactivation by â-lactamase. Cx also is a â-lactam antibiotic. The effect of antibiotics used to eliminate $A$. tumefaciens varies with plant species and explant type (Nauerby et al., 1997). In maize embryogenic callus, $\mathrm{Cx}$ enhanced the morphogenesis, increased root and shoot length (Danilova and Dolgikh, 2004). Tambarussi et al. (2015) studied the effect of several concentrations of timentin, cefotaxime and carbenicillin on shoot regenerationfrom teak explants (Tectona grandis L.). They observed that $300 \mathrm{mg} \mathrm{L}^{-}$ ${ }^{1} \mathrm{Cx}$ stimulated this regeneration process while 500 $\mathrm{mg} \mathrm{L}^{-1}$ inhibited it. The authors attributed this response mainly to the interaction between the endogenous hormonal concentrations and the product of â-lactam antibiotic breakdown that may affect, positively or negatively, the shoot regeneration. In the present study, the same concentration of cefotaxime $\left(500 \mathrm{mg} \mathrm{L}^{-1}\right)$ inhibited shoot regeneration from callus.

Acetosyringone (AS) is a phenolic compound involved in plant-pathogen recognition. The mechanism of activation

Revista Árvore. 2017;41(3):e410315 
of vir genes by these compounds is well known in the case of A. tumefaciens (Lee et al., 1995). In the present study, the addition of $\operatorname{AS}(50 \mu \mathrm{M})$ to the liquid and solid co-culture media had a positive effect on gus gene expression. The concentrations used by other authors vary in each case and sometimes are superior to $50 \mu \mathrm{M}$. For example, Jha et al. (2011) tested three concentrations $(100,200$ and $400 \mu \mathrm{M})$ during the co-culture of caulinar apexes of Pennisetum glaucum and obtained the highest transformation frequency (5.79\%) with $400 \mu \mathrm{M}$. On the other hand, Dutta et al. (2013) added $200 \mu \mathrm{M}$ AS to the liquid medium for one day-pre-culture of Leptadenia pyrothnica explants and found 14\% of gus positive explants. For Agrobacterium-mediated transformation of Cassia occidentalis, the concentration of acetosyringone was the critical parameter during the co-cultivation process (Rajagopal et al., 2014).The number of gus-positive spots per explant was increased 6 fold when the infection process was carried out with acetosyringone in the co-culture medium (400iM) and in bacterial suspension (50iM) (Rajagopal et al., 2014).

\section{CONCLUSIONS}

Some progress in transformation efficiency was reached in this study, especially by using Augmentin instead of Cefotaxime and incorporating acetosyringone into co-culture media. The use of $12.5 \mathrm{mg} . \mathrm{L}^{-1} \mathrm{Km}$ is efficient for transformed material selection and transformation efficiency was increased in comparison with that reached by Dibax et al. (2010) for the same species.

\section{ACKNOWLEDGMENTS}

The authors are thankful to Dr. D. S. Domingues, Laboratory of Plant Biotechnology, IAPAR, Londrina, Brazil, for providing the Agrobacterium strain, to Eileen

Bagyary for editing the manuscript and to CNPq for a grant to Y. de O.C.

\section{REFERENCES}

Alcantara GB, Bespalhok Filho JC, Quoirin M. Organogenesis and transient genetic transformation of the hybrid Eucalyptus grandis $\times$ Eucalyptus urophylla. Scientia Agricola. 2011; 68(2):246-51.

Ahmad I, Hussain T, Ashraf I, Nafees M, Rafay M. et al. Lethal effects of secondary metabolites on plant tissue culture. American-Eurasian Journal of Agricultural \& Environmental Science. 2013;13:539-47.

Ali AA, Alqurainy F. Activities of antioxidants in plants under environmental stress. In: The luteinprevention and treatment for diseases. Transworld Research Network; 2006. p.187-256.

Danilova SA, Dolgikh YI. The stimulatory effect of the antibiotic cefotaxime on plant regeneration in maize tissue culture. Russian Journal of Plant Physiology. 2004;51:559-62.

Dayarani M, Dhanarajan MS.Control of excessive browning during in-vitro regeneration of Musa laterita. International Journal of Pharma \& Bio Sciences. 2013;4(3B):471-6.

Dibax R, Eisfeld CL, Cuquel F, Koehler H, Quoirin M. Plant regeneration from cotyledonary explants of Eucalyptus camaldulensis. Scientia Agricola. 2005;62:406-412. 3

Dibax R, Deschamps C, Bespalhok Filho JC, Vieira LGE, Molinari HBC, Campos MKF et al. Organogenesis and Agrobacterium tumefaciens mediated transformation of Eucalyptus saligna with P5CS gene. Biologia Plantarum. 2010;54:6-12.

Doyle JJ, Doyle JL. A rapid DNA isolation procedure for small quantities of fresh leaf tissue. Phytochemical Bulletin. 1987;19:11-5.

Dutta I, Kottackal M, Tumimbang E, Tajima H, Zaid A, Blumwald E. Sonication-assisted efficient Agrobacterium-mediated genetic transformation of the multipurpose woody desert shrub Leptadenia pyrotechnica. Plant Cell, Tissue and Organ Culture. 2013;112:289-301.

Fett-Neto AG, Fett JP, Goulart LWV, Pasquali G, Termignoni RR, Ferreira AG. Distinct effects of auxin and light on adventitious root development in Eucalyptus saligna and Eucalyptus globulus. Tree Physiology. 2001;21:457-64.

Girijashankar V. Genetic transformation of eucalyptus. Physiology and Molecular Biology of Plants. 2011;17:9-23.

George EF, Davies W. Effects of the physical environment. In: George EF, Hall MA, De Klerk GJ. Plant propagation by tissue culture. $3^{\text {rd }}$. ed. Dordrecht: Springer; 2008. v.1. p.423-64. 
Gonzales ER, Andrade A, Bertolo AL, Lacerda GC, Carneiro RT, Prado Defávari VA et al. The efficiency of aminoglycoside antibiotics in the regeneration and selection of Eucalyptus spp. In: Proceedings of the International Conference Eucalyptus in the Mediterranean Basin: perspectives and new utilizations. Taormina: 2000.

Ho CK, Chang SH, Tsay CJ, Chiang VL, Chen ZZ. Agrobacterium tumefaciens mediated transformation of Eucalyptus camaldulensis and production of transgenic plants. Plant Cell Reports. 1998;17:675-80.

Hood EE, Gelvin SB, Melchers LS, Hoekema A. New Agrobacterium helper plasmids for gene transfer to plants. Transgenic Research. 1993;2:208-18.

Iwakiri S, Matos JLM, Prata JG, Trianoski R, Silva LS. Evaluation of the use potential of nine species of genus Eucalyptus for production of veneers and plywood panels. Cerne. 2013;19:263-9.

Jefferson RA. Assaying chimeric genes in plants: the GUS gene fusion system. Plant Molecular Biology Reporter. 1987;5:387-405.

Jha P, Rustagi A, Agnihotri PK, Kulkarni VM, Bhat V. Efficient Agrobacterium-mediated transformation of Pennisetum glaucum (L.) R. Br. using shoot apices as explant source. Plant Cell, Tissue and Organ Culture. 2011;107:501-12.

Lee YW, Jin S, Sim WS, Nester EW. Genetic evidence for direct sensing of phenolic compounds by the VirA protein of Agrobacterium tumefaciens. Proceedings of the National Academy of Sciences USA. 1995;92:12245-9.

Li J, Komori S, Sasaki K, Mimida N, Matsumoto S, Wada $\mathrm{M}$ et al. Pre-culture before Agrobacterium infection to leaf segments and meropenem improve the transformation efficiency of apple (Malus $x$ domestica Borkh). Journal of the Japanese Society of Horticultural Science. 2011;80:244-54.

MacRae S, Van Staden J. Transgenic Eucalyptus. In: Bajaj YPS. Biotechnology in Agriculture and Forestry; Transgenic trees. Berlin: Heidelberg, Springer-Verlag, 1999. p.88-114. v.44.
Mendonça EG, Stein VC, Balieiro FP, Lima CDF, Santos BR, Paiva LV. Genetic transformation of Eucalyptus camaldulensis by agrobalistic method. Revista Árvore. 2013;37:419-29.

Misra P, Toppo DD, Gupta N, Chakrabarty D, Tuli R. Effect of antioxidant and associate changes in antioxidant enzymes in controlling browning and necrosis of proliferating shoots of elite Jatropha curcas L. Biomass \& Bioenergy. 2010;34:1861-9.

Moralejo M, Rochange F, Boudet AM, Teulières C. Generation of transgenic Eucalyptus globulus plantlets through Agrobacterium tumefaciensmediated transformation. Australian Journal of Plant Physiology. 1998;25:207-12.

Mullins KV, Llewellyn DJ, Hartney VJ, Strauss S, Dennis SE. Regeneration and transformation of Eucalyptus camaldulensis. Plant Cell Reports. 1997;16:787-91.

Murashige T, Skoog F. A revised medium for rapid growth and bioassay with tobacco tissue cultures. Physiologia Plantarum. 1962;15:473-97.

Nauerby B, Billing K, Wyndaele R. Influence of the antibiotic timentin on plant regeneration compared to carbenicillin and cefotaxime in concentrations suitable for elimination of Agrobacterium tumefaciens. Plant Science. 1997;123:169-77.

Nawar WW. Lipids. In: Fennema OR. Food chemistry. $3^{\text {rd }}$ ed. New York: Marcel Dekker; 1996. p.225-320.

Ogawa Y, Mii M. Evaluation of 12 â-lactam antibiotics for Agrobacterium-mediated transformation through in planta antibacterial activities and phytotoxicities. Plant Cell Reports. 2005;23:736-43.

Prakash MG, Gurumurthi K. Genetic transformation and regeneration of transgenic plants from precultured cotyledon and hypocotyl explants of Eucalyptus tereticornis Sm. using Agrobacterium tumefaciens. In Vitro Cellular and Developmental Biology-Plant. 2009;45:429-34.

Quisen RC, Oliveira Y, Pileggi M, Cuquel F, Quoirin M. Selective agents and A. tumefaciens overgrowth-control antibiotics in Eucalyptus

Revista Árvore. 2017;41(3):e410315 
camaldulensis cotiledonary culture. Brazilian Archives of Biology and Technology. 2009;52:1485-92.

Rajagopal M, Balakrishna A, Reddy SR, Srinivas B. Factors influencing Agrobacterium-mediated transient expression of uidA in Cassia occidentalis Linn explants. International Journal of Pharma and Bio Sciences. 2014;5:B840-B855.

Raju PS, Bawa AS. Food additives in fruit processing. In: Hui YH. Handbook of fruits and fruits processing. Iowa: Blackwell Publishing; 2006.

Seong ES, Song KJ. Factors affecting the early gene transfer step in the development of transgenic "Fuji" apple plants. Plant Growth Regulation. 2008;54:81-95.

Silva FAS, Azevedo CAV. Principal components analysis in the Software Assistat-Statistical Attendance. In: Proceedings of the $7^{\text {th }}$. World Congress on computers in Agriculture. Reno: American Society of Agricultural and Biological Engineers; 2009.

Sistema Nacional de Informações Florestais. SNIF. [acessado em: 23 de ago. de 2015]. Disponível em: http://www.florestal.gov.br/snif/ recursos-florestais/as-florestas-plantadas.
Suaréz E, Pérez-Francés JF, Rodríguez-Pérez JA. Use of multinodal explants for micropropagation of Leucodendron 'Safari Sunset'. Span Journal of Agricultural Research. 2010;8:790-6.

Subbaiah MM, Minocha SC. Shoot regeneration from stem and leaf callus of Eucalyptus tereticornis. Plant Cell Reports. 1990;9:370-3.

Tambarussi EV, Rogalski M, Nogueira FTS, Brondani GE, De Martin VF, Carrer H. Influence of antibiotics on indirect organogenesis of Teak. Annals of Forest Research. 2015;58:177-83.

Tiwari S, Tuli R. Optimization of factors for efficient recovery of transgenic peanut (Arachis hypogaea L.). Plant Cell, Tissue and Organ Culture. 2012;109:111-21.

Tournier V, Grat S, Marque C, El Kayal W, Penchel $\mathrm{R}$, Andrade $\mathrm{G}$ et al. An efficient procedure to stably introduce genes into an economically important pulp tree (Eucalyptus grandis $\mathrm{x}$ Eucalyptus urophylla). Transgenic Research. 2003;12:403-11.

Zhou B, Wei X, Wang R, Jia J. Quantification of the enzymatic browning and secondary metabolites in the callus culture system of Nigella glandulifera Freyn et Sint. Asian Journal of Traditional Medicines. 2010;5:109-116. 